\section{A consumer-driven approach}

Asia's Media Innovators Vol 2 , edited by Stephen Quinn and Kim Kierans. Singapore: Konrad Adenauer Stiftung. 2010. 137 pp. No ISBN. www.kas.de/wf/doc/kas_21583-1522-2-30. pdf?110126051529 (free download)

$\mathrm{T}$ HIS BOOK is a second volume of studies of innovations at selected media companies in the Asia-Pacific region. The earlier edition dealt with an account of the some of the key players in the Asian media landscape and their dynamics; this volume engages more with the social factors, trends and consumer practices that become the driving force for these players.

Most Asian countries are less developed than the North America and Europe and face several economic and political problems. Yet they are one of the fastest growing markets for the new media technologies and their people are potentially the biggest users of social media and social networking.

How do social media in Asia cope with economic and political challenges? What makes the Philippines 'the social networking capital of the world'? How does twittering and micro-blogging promote 'citizen journalism'? What consumers' behavioural changes makes Facebook,

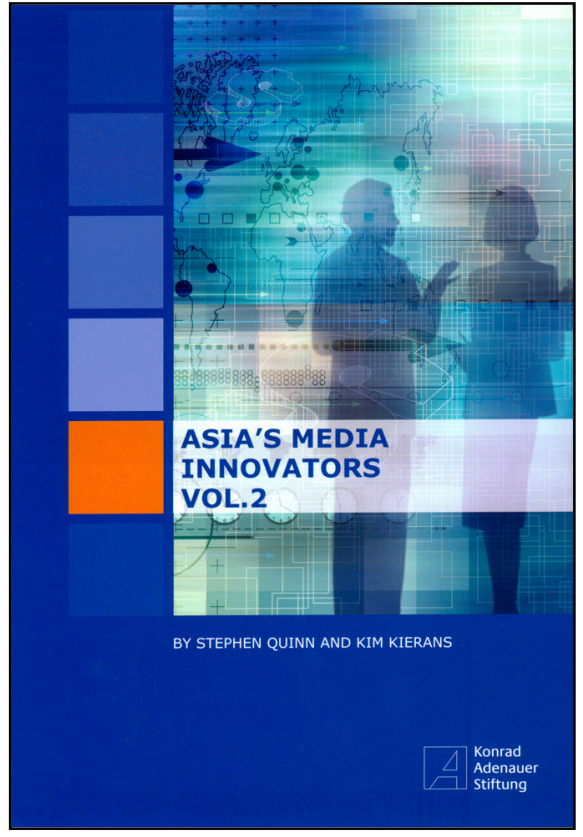

MySpace and YouTube so successful? And what are the future challenges of Asia's media companies as innovative providers? Co-authors Quinn and Kierans examine all these issues.

The book is divided into ten chapters, covering a range of new media innovations in various countries of the region. Each chapter focuses of the trends and usage of a particular form of media in each country starting from the Citizen-aided news in the Philippines, blogging in Vietnam, internet usage in Singapore and Phuket and continuing with tweeting in Australia, digital media in Malaysia and mobile phone penetration in India and China. It concludes with the possible trends 
and growth of new media predicting future trends in these countries.

The authors give a detailed account of the new media developments in each country, providing facts and figures in the form of tables, graphs and charts to explain situations in several Asian markets. Surprisingly, they have ignored Pakistan as one of the biggest markets of the mobile phone industry. The use of mobile phones is flourishing in Pakistan, not only as a tool for social networking. It has offered new opportunities in the traditional media to fight state censorship.

Newspapers and television channels are using mobile phones to provide news that cannot be published or broadcast. In 2009, GEO TV channel used mobile phone networks to air two of its weekly political talk shows as 'citizen broadcasts' that were banned from being aired by the former President Musharaf due to political reasons. It might be worthwhile for the authors to include a chapter on such innovations to demonstrate the element of 'social empowerment' in their next edition. - Rukhsana Aslam is a media educator and a doctoral candidate at AUT University.

\section{IN SEARCH OFTHE FRIENDLY ISLANDS}

\section{TONGA ANDTHE MEDIA}

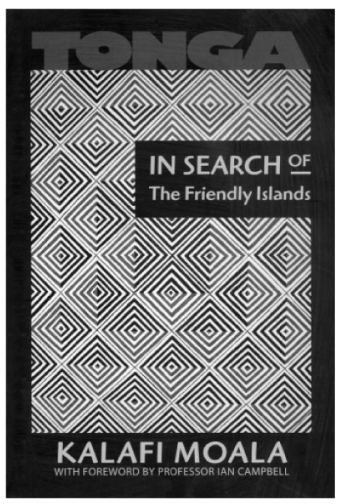

\section{By Kalafi Moala}

THIS IS A SOUL-SEARCHING BOOK ABOUT THE FUTURE OF THE PACIFIC KINGDOM AS IT PURSUES DEMOCRATIC

CHANGES IN THE WAKE OF THE NOVEMBER 2006 URBAN RIOT AND HOW THE MEDIA IS FACING UP TO THE CHANGES.

ISBN 978-1-877314-75-9. Published by THE Pasifika Foundation in Hawaíl and the Pacific Media Centre.

PACIFIC MEDIA CENTRE AUTUNIVERSITY

ORder from WheELERS Books WWW.WHEELERS.CO.NZ

AND BOOKSHOPS MORE INFORMATION: WWW.PMC.AUT.AC.NZ PRICE: NZ\$35

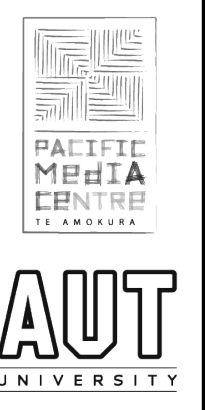

